Article

\title{
Sensory Characteristics and Volatile Compounds of Herbal Teas and Mixtures of Bush Tea with Other Selected Herbal Teas of South Africa
}

\author{
Florence Malongane ${ }^{1} \oplus$, Lyndy Joy McGaw $^{2} \oplus$, Legesse Kassa Debusho ${ }^{3} \odot$ and \\ Fhatuwani Nixwell Mudau 4,5,*iD \\ 1 Department of Life and Consumer Sciences, College of Agriculture and Environmental Sciences, \\ University of South Africa, Private Bag X6, Florida 1710, South Africa; malonf@unisa.ac.za \\ 2 Phytomedicine Programme, Department of Paraclinical Sciences, University of Pretoria, Private Bag X04, \\ Onderstepoort, Pretoria 0110, South Africa; lyndy.mcgaw@up.ac.za \\ 3 Department of Statistics, College of Science, Engineering \& Technology, University of South Africa, \\ Private Bag X6, Florida 1710, South Africa; debuslk@unisa.ac.za \\ 4 Department of Agriculture and Animal Health, College of Agriculture and Environmental Sciences, \\ University of South Africa, Private Bag X6, Florida 1710, South Africa \\ 5 School of Agriculture, Earth and Environmental Sciences, University of Kwazulu Natal, P. Bag X01, \\ Scottsville, Pietermaritzburg 3209, South Africa \\ * Correspondence: mudauf@ukzn.ac.za; Tel.: +27-33-260-6076
}

Received: 30 January 2020; Accepted: 30 March 2020; Published: 14 April 2020

\begin{abstract}
South Africa has a traditional heritage of using indigenous herbal teas, and the demand for herbal teas motivated by the functional health benefits has far exceeded global supply. This has led to worldwide interest in the sensory characteristics and volatile compound characterisation of herbal drink formulations. The objective of this study was to investigate the descriptive sensory analysis and volatile compounds of bush, special, honeybush and rooibos tea and the blend of bush tea with special, honeybush and rooibos, respectively. The trained sensory panel scored each tea sample for aroma, taste, aftertaste and mouthfeel attributes using sensory evaluation practices. Compound identification was performed by gas chromatography connected to a mass spectrometer (GC-MS). The results of the study demonstrated that rooibos and honeybush tea had an overall sweet-caramel, honey-sweet, perfume floral and woody aroma while bush tea and special tea depicted green-cut grass, dry green herbal and astringent/dry mouth feel. The GC-MS analyses depicted the following compounds 2-furanmethanol, 2-methoxy-4-vinylphenol, D-limonene, dihydroactinidolide, linalool, (E,E)-2,4-heptadienal, and phytol. The blending of bush tea with rooibos and honeybush tea toned down its astringent mouth feel. Compounds identified in this study may be useful markers for potential herbal tea sensory characteristics.
\end{abstract}

Keywords: herbal tea; GC-MS; flavour; volatile compounds; descriptive sensory evaluation

\section{Introduction}

South Africa has a traditional heritage of using indigenous herbs to make tea, with the most popular being rooibos tea (Aspalathus linearis), honeybush tea (Cyclopia species), bush tea (Athrixia phylicoides) and special tea (Monsonia burkeana) [1]. Rooibos tea has been commercialised and is currently distributed in local and international markets such as Germany (31\%), Netherlands (16\%), Japan (15\%), the United Kingdom (11\%), United States of America (7\%) and the remaining 20\% is exported to India and Sri Lanka [2]. Similarly, honeybush tea comprising a blend of Cyclopia species, usually C. intermedia, C. genistoides and C. subternata, is also exported to the international market [3]. However, bush and 
special tea, the herbal teas used in former homeland areas of South Africa, have not yet been fully explored, mainly due to the underproduction and unavailability of these teas in the formal market, although they are traded in the informal market in large quantities [4]. Both these teas possess good antibacterial and anti-oxidant properties [5,6]. Increased knowledge of these teas will increase diversity and create more opportunities for a sustainable herbal tea market in South Africa.

Research on descriptive sensory and volatile compounds analysis has focused on rooibos and honeybush tea due to their worldwide consumer demand and with the aim of producing appealing competitive products [2,3]. There are currently no reported results on the sensory analysis of bush and special tea, nor has any study been carried out on the sensory analysis of bush tea blended with special, rooibos and honeybush teas. The sensory attribute characteristics of fermented rooibos tea are honey, woody and herbal-floral flavours, a slightly sweet taste, astringent, caramel flavour and a sweet-associated fruity flavour [7]. Furthermore, Jolley et al. [2] reported aroma characteristics of rooibos as fynbos-floral, honey, hay/dried grass and rooibos-woody. The sensory characteristics of fermented honeybush tea are listed as fynbos-sweet, fynbos-floral, woody, sweet and slightly astringent mouthfeel [3]. The analysis of the selected tea samples will enable the profiling of the sensory characteristics of both the commercial and non-commercial teas in order to deduce the consumer acceptability of the non-commercial teas. Additionally, the blending of bush tea with other herbal teas could increase the sensory appeal and strengthen its potential for commercialisation.

The consumption of herbal teas has increased in South Africa with the growth in production of rooibos and honeybush teas, as well as other non-commercial herbal tea species such as bush tea [8]. Herbal teas are infusions made from fruits, leaves, flowers, roots and stems of plants and are intended for oral aqueous consumption [9]. The increased use of herbal teas is attributed to their sensory properties (aroma and taste) and perceived health benefits [8].

The combination of sensory and chemical analysis data can provide more insight into product characteristics and useful markers for tea sensory characteristics [10]. However, data describing the chemical compositions and sensory attributes of both bush and special tea are lacking. Therefore, the objective of this study was to determine sensory and volatile compounds following the blending of these selected teas with known commercial herbal teas.

\section{Material and Methods}

\subsection{Plant Materials}

Seven tea samples including bush tea, special tea, honeybush tea and rooibos tea as well as three blends of bush tea in a 1:1 ratio (bush + rooibos tea, bush + honeybush tea and bush + special tea) were characterised for their sensory attributes and volatile compound constitution. Bush tea samples were collected from the Agricultural Research Council (Pretoria, South Africa), special tea leaves from Hartbeespoort (North West Province, South Africa) while rooibos (Aspalathus linearis) and honeybush (Cyclopia species) tea samples were bought from a local market in Florida, Johannesburg (Gauteng Province, South Africa). The four South African herbal teas were selected on the basis that they were locally produced.

\subsection{Descriptive Sensory Evaluation}

Descriptive sensory analysis (DSA) was conducted in the Sensory Analysis Unit of the Agricultural Research Council (ARC) in Irene, South Africa. The method includes determining product descriptors, examining the sensory perceived attributes and measuring the intensities of those attributes by trained panellists whose roles were more like analytical tools or instruments in that they described what attributes were perceived and how strong/intense they were. 


\subsubsection{Procedure-Preparation}

The leaves of special tea and bush tea were oven-dried at $50{ }^{\circ} \mathrm{C}$ for $48 \mathrm{~h}$ and then ground to a coarse powder resembling un-ground rooibos tea. The tea powders were stored in glass jars and in a dark place until further analysis. Bush tea was blended with the other three teas at a ratio of 1:1 $(w / w)$. Twenty grams ( $20 \mathrm{~g}$ ) of each tea sample was placed in porcelain kettles pre-heated to $70{ }^{\circ} \mathrm{C}$ in an oven to avoid rapid cooling of water after which $1 \mathrm{~L}$ of boiling distilled water was poured into the porcelain tea pot. Tea was allowed to brew for 5 min according to the descriptions of Welna et al. [11] while being kept warm in a heated oven $\left(70^{\circ} \mathrm{C}\right)$. Brewed tea was sieved and poured into warmed porcelain cups and covered immediately with Petri dish lids. Each panel member was served immediately with $100 \mathrm{~mL}$ of brewed tea per session. Tasting of the tea samples was randomised over four days in sessions lasting approximately $10 \mathrm{~min}$ so that each product had an equal opportunity to be tasted first. Panellists evaluated products in separate tasting booths to reduce distraction and panellist interaction and to ensure uninterrupted and unbiased individual responses. All products were coded with a three-digit random code and presented blindly to the panellists. Tea was evaluated under red light conditions to mask the colour differences. Water biscuits from a local market and distilled water at room temperature were served as palate cleansers in between evaluation sessions as previously described $[12,13]$. Care was taken to ensure that each sample was identically treated with respect to the volume served and serving temperature of each replication of the tea samples.

The actual tasting was conducted according to the method described by Owuor [14]. Briefly, the testing was carried out by sucking, rather than sipping, so that the liquor is drawn to the back of the mouth, on an inward breath, and up to the olfactory nerve in the nose. The liquor was then swished backwards and forwards and brought into contact with the tongue, palate, and other areas of the mouth where sensory receptors are located. In this way, the panellists were able to feel, taste, and smell the liquor virtually simultaneously and were thus able to determine its briskness, strength, body and flavour. The liquor was taken directly from the cup and discarded into a disposable cup after tasting.

\subsubsection{Taste Panel Procedures}

Ten (10) experienced trained panellists from the Agricultural Research Council - Animal Production Institute (Irene, Pretoria, South Africa) who had previously participated in the descriptive sensory evaluation of beverages, meat and vegetables, were selected for the project. The ten trained panellists were a representative sample to produce good quality data [15]. The panellists were informed not to use perfumed cosmetics, to avoid exposure to foods and/or fragrances at least an hour before the evaluation sessions and to avoid burning their oral cavity with any liquid as described by Lee et al. [16]. Prior to DSA, the panellists discussed sensory attributes of the seven tea samples during the preliminary four sessions, each lasting $120 \mathrm{~min}$ until they agreed on 26 sensory descriptors (Table 1). A category rating scale, with zero (0) denoting no perceived flavour (e.g., no sweet-caramel, maple syrup aroma) and seven (7) denoting the most intense condition (e.g., extremely intense sweet-caramel, maple syrup) was constructed and used to evaluate the different samples.

Table 1. Descriptions of sensory attributes of teas.

\begin{tabular}{cc}
\hline Attributes & Description \\
\hline Aroma & $\begin{array}{c}\text { Aromatics associated with materials that also have a sweet taste, such as } \\
\text { molasses, caramelised sugar and maple syrup. }\end{array}$ \\
\hline Sweet-caramel, maple syrup & $\begin{array}{r}\text { Aromatics associated with the sweet, caramelised flora and woody } \\
\text { aromatic associated with honey. }\end{array}$ \\
\hline Honey-sweet typical honey & Aromatics associated with green cut grass, fresh-cut grass, mint. \\
\hline
\end{tabular}


Table 1. Cont.

\begin{tabular}{|c|c|}
\hline Attributes & Description \\
\hline \multicolumn{2}{|l|}{ Aroma } \\
\hline Cooked spinach & Aromatics associated with cooked spinach. \\
\hline Dry green herbal—chai tea & $\begin{array}{c}\text { Aromatics associated with "Green" flavour typical of dried grass or } \\
\text { dried herbs. }\end{array}$ \\
\hline $\begin{array}{l}\text { Earthy_-boiled potatoes, damp } \\
\text { potting soil }\end{array}$ & Aromatics associated with damp soil, wet foliage, and damp potting soil. \\
\hline Perfume-floral, lavender & $\begin{array}{c}\text { Aromatics associated with having a light fragrant aromatic characteristic } \\
\text { of lavender. }\end{array}$ \\
\hline $\begin{array}{l}\text { Woody cinnamon, dry } \\
\text { dusty, bark }\end{array}$ & Aromatics associated with dry fresh-cut wood; bark, cinnamon, dust. \\
\hline \multicolumn{2}{|l|}{ Taste-Flavour } \\
\hline Bitter-quinine, caffeine & $\begin{array}{l}\text { Flavours associated with the taste on the tongue stimulated by solutions of } \\
\text { caffeine, quinine. }\end{array}$ \\
\hline Sweet—caramel, maple syrup & $\begin{array}{l}\text { Flavours associated with materials that also have a sweet taste, such as } \\
\text { molasses, caramelised sugar, and maple syrup. }\end{array}$ \\
\hline Honey—sweet typical honey & $\begin{array}{l}\text { Flavours associated with the sweet, caramelised flora and woody aromatic } \\
\text { associated with honey. }\end{array}$ \\
\hline Rooibos & $\begin{array}{l}\text { Flavours associated with a combination of honey, woody and herbal-floral } \\
\text { notes with a slightly sweet taste and subtle astringency. }\end{array}$ \\
\hline Green—cut grass, mint & Flavours associated with green cut grass, fresh-cut grass, mint. \\
\hline Cooked spinach & Flavours associated with cooked spinach. \\
\hline Dry green herbal—chai tea & Flavours associated with "Green" flavour typical of dried grass or dried herbs. \\
\hline $\begin{array}{l}\text { Earthy_-boiled potatoes, damp } \\
\text { potting soil }\end{array}$ & $\begin{array}{l}\text { Flavours associated with damp soil, wet foliage, or slightly undercooked } \\
\text { boiled potato, damp potting soil. }\end{array}$ \\
\hline Fruity-peach, mango-like & Flavours associated with a mixture of peach-mango like fruits. \\
\hline Perfume-floral, lavender & Flavours associated with a light fragrant aromatic characteristic of lavender. \\
\hline $\begin{array}{l}\text { Woody cinnamon, dry } \\
\text { dusty, bark }\end{array}$ & Flavours associated with dry fresh-cut wood; bark, cinnamon, dust. \\
\hline Medicinal & Flavours associated with dried grass or dried herbs used in herbal medication. \\
\hline \multicolumn{2}{|l|}{ Aftertaste } \\
\hline Bitter & $\begin{array}{l}\text { Aftertaste associated with the taste on the tongue stimulated by solutions of } \\
\text { caffeine, quinine. }\end{array}$ \\
\hline Green-cut grass, mint & Aftertaste associated with green cut grass, fresh-cut grass, mint. \\
\hline Cooked spinach & Aftertaste associated with cooked spinach. \\
\hline Dry green herbal—chai tea & $\begin{array}{c}\text { Aftertaste associated with "Green" flavour typical of dried grass or } \\
\text { dried herbs. }\end{array}$ \\
\hline $\begin{array}{l}\text { Woody-cinnamon, dry } \\
\text { dusty, bark }\end{array}$ & Aftertaste associated with dry fresh-cut wood, bark, cinnamon, dust. \\
\hline $\begin{array}{l}\text { Earthy_-boiled potatoes, damp } \\
\text { potting soil }\end{array}$ & $\begin{array}{l}\text { Aftertaste associated with damp soil, wet foliage, or slightly undercooked } \\
\text { boiled potato, or damp potting soil. }\end{array}$ \\
\hline \multicolumn{2}{|l|}{ Mouthfeel } \\
\hline Astringent/dry & $\begin{array}{l}\text { The chemical feeling factor on the tongue or other skin surfaces of the oral } \\
\text { cavity described as puckering/dry and associated with tannins or alum } \\
\text { (unripe banana, strong tea, anise, allspice) }\end{array}$ \\
\hline
\end{tabular}




\subsection{Gas Chromatography-Mass Spectrometry}

\subsubsection{Tea Samples}

The water extraction method was used for the preparation of all tea samples. In brief, $4 \mathrm{~g}$ of each tea sample was placed in a $50 \mathrm{~mL}$ centrifuge tube followed by the addition of $40 \mathrm{~mL}$ of boiled $\left(100{ }^{\circ} \mathrm{C}\right)$ deionised water to each sample as previously described [17]. The mixtures were vigorously shaken, sonicated and then centrifuged; each step lasted $10 \mathrm{~min}$. The resultant liquid was filtered into a beaker through Whatman No. 1 filter paper ( $11 \mu \mathrm{m}$ pore size). The extraction was repeated using $20 \mathrm{~mL}$ and then $10 \mathrm{~mL}$ of boiled deionised water on the same plant material. The filtered tea extracts were stored at $-80^{\circ} \mathrm{C}$ overnight, and then freeze-dried. All tea extracts were reconstituted in methanol (Sigma Aldrich) and dichloromethane (Sigma Aldrich) at a ratio of 1:1 to a concentration of $100 \mathrm{mg} / \mathrm{mL}$. Tea supernatants were placed directly into $2 \mathrm{~mL}$ amber screw-top vials. The samples for the gas chromatography-mass spectrometer (GC-MS) were prepared and analysed in triplicate.

\subsubsection{Gas Chromatography-Mass Spectrometry}

The samples were analysed by gas chromatography (Agilent Technologies 7890B) that was equipped with a LECO, Pegasus 4-D GC X GC-TOF MS detector and Gerstel multi-purpose sampler (GMbH and Co. KG, 45473 Mülheim an der Ruhr, Germany). The oven was equipped with an Agilent HP-5MS column $(30 \mathrm{~m} \times 0.25 \mathrm{~mm} \times 0.25 \mu \mathrm{m}$ film thickness) fused silica capillary column.

The Helium carrier gas (percentage purity $>99.999 \%$ ) was maintained at a constant flow of $1.5 \mathrm{~mL} / \mathrm{min}$. A $1.5 \mu \mathrm{L}$ splitless injection volume was used with an inlet temperature of $250{ }^{\circ} \mathrm{C}$. The chromatographic separation was achieved by using the following temperature program. The temperature was initially set at $35^{\circ} \mathrm{C}$ (held for $1 \mathrm{~min}$ ), and then increased to $142^{\circ} \mathrm{C}$ at a ramp rate of $5{ }^{\circ} \mathrm{C} / \mathrm{min}$ (held for $3 \mathrm{~min}$ ), then increased further to $240^{\circ} \mathrm{C}$ at $5^{\circ} \mathrm{C} / \mathrm{min}$. The transfer line temperature was maintained at $225^{\circ} \mathrm{C}$. The MS ion source temperature was $200^{\circ} \mathrm{C}$ with filament bias of -70 voltage. The MS mass range units were 40 to 550 atomic mass units (amu), with the acquisition rate of 10 spectra per second while the detector voltage was 1670 . The total GC run time was $90 \mathrm{~min}$.

The mass spectrometer was operated in full-scan mode, and the peak area was determined by ChemStation software (Agilent Technologies). Tentative identifications of volatile compounds were based on matching mass spectra of unknowns with those of the reference database (NIST Mass Spectral Data 98 edition) according to the descriptions of Wu et al. [18].

\subsection{Statistical Techniques}

The data obtained from the sensory panel were analysed using the repeated measures analysis of variance (ANOVA) to compare all the sensory attributes measured among tea samples. Samples for GC-MS were prepared and analysed in triplicate. The comparison of each GC-MS measurement (variables) among tea samples was done utilizing one-way ANOVA. The Tukey's (Honest significant difference) HSD test was applied for pairwise means comparison of tea samples, at a 5\% level of significance. Principal component analysis (PCA) was used in this study to determine whether there were differences in levels of descriptive sensory attributes among the seven tea samples. A partial least square regression analysis was performed using the covariance matrix to determine the relationship between the data from the sensory panel and the GC-MS data. All the analyses were done using JMP ${ }^{\circledR}$, Version 13 (SAS Institute Inc., 2016).

\subsection{Ethics Approval}

The study was reviewed in compliance with the Unisa Policy on Research Ethics by the College of Agriculture and Environmental Sciences (CAES) research ethics review committee. The approval was granted before the study began. 


\section{Results and Discussion}

\subsection{Descriptive Sensory Analysis}

The aroma attributes such as sweet-caramel, honey, green-cut grass, cooked spinach, dry green herbal, earthy, perfume-floral and woody-cinnamon; the taste such as, bitter-quinine, sweet-caramel, honey, rooibos, green-cut grass, cooked spinach, dry green herbal, earthy, fruity-peach, perfume-floral, woody-cinnamon and medicinal; the aftertaste including, bitter, green-cut grass, cooked spinach, dry green herbal, woody-cinnamon and earthy; and the mouthfeel such as astringent/dry, were evaluated. Some aroma attributes were similar to those found in rooibos, honeybush and black tea, which were woody, honey and green. The mean scores and the significant difference for all 26 attributes are described in Table 2. Supplementary material (Table S1) contains raw data from descriptive sensory evaluation.

\subsubsection{Aroma}

According to the results given in Table 2, sweet-caramel, honey-sweet, perfume-floral and woody aromas were more prominent in the rooibos and honeybush teas, though at a low intensity. Theron et al. [3] reported a fynbos-floral, fynbos-sweet, cinnamon and woody aroma in honeybush tea, which is in agreement with the findings of the present study. The aroma characteristics of rooibos previously discussed were rooibos woody, fynbos-floral and honey [2]. Green-cut grass, dry green herbal were very low in rooibos and honeybush teas, but noticeably higher in bush tea, special tea and all three bush tea blends. Special tea had the most intense cooked spinach aroma and as a result scored high in bush-special tea blend. There was only a hint of earthy boiled potatoes and damp potting soil aroma in all seven samples. There are no previously reported aroma characteristics of special tea and bush tea, nor of the blend of bush tea, making this the first study to report such results.

\subsubsection{Taste Profile}

The taste profiles of all teas are presented in Table 2. The strongest bitter-quinine, caffeine flavour was detected in bush, special tea and the bush tea and special tea blend. High intensities for bush tea also increased scores for the bush and honeybush tea blends and bush and rooibos tea blends. In the current study, bush and special tea were not fully fermented compared to rooibos and honeybush teas, which underwent a quality control fermentation process. A previous study demonstrated that the fermentation process reduces the bitterness in tea [19], and such could be the case with the bitter taste found in bush and special tea. In the production of rooibos tea, the process includes the formation of sweet, apple-like or honey caramel, after which the fermentation process is halted, thus ensuring the characteristics of sweet in the final product [20]. The sweet-caramel and typical honey-sweet flavours were similar to the aroma more prominent in rooibos and honeybush tea, and consequently increased the scores of their respective blends with bush tea. In contrast, there was only a hint of honey-sweet typical honey flavor in the bush tea, special tea and the bush and special tea blend. Rooibos flavour was the highest in the rooibos and honeybush teas, followed by bush-rooibos and bush-honeybush tea blends, and was the least intense in bush tea and special tea. Blending bush tea with rooibos and honeybush teas increased the intensity of sweet-caramel, honey-sweet and rooibos, providing a modifying factor to the bitter taste of bush tea alone. Bush tea was the only tea with a high score of intense green-cut grass taste. Special tea and the special-bush tea blend were the only two teas with an intense cooked spinach and medicinal flavour. According to the results, the strongest dry green herbal taste was detected in bush tea, special tea, bush-rooibos tea blend, bush-honeybush tea blend and bush-special tea blend. Overall, for all seven teas, the earthy boiled potatoes and woody cinnamon were of a low intensity. The perfume-floral lavender-was only intense in the honeybush tea and the bush-honeybush tea blend. This is the distinguishing factor of honeybush compared to other teas in the study. 


\subsubsection{Aftertaste and Mouthfeel of Seven Teas}

The bitter and green-cut grass aftertaste was more prominent in bush tea, special tea and all bush tea blends, similar to the results in the tasty flavour. The cooked spinach aftertaste was more intense in the special tea and bush-special tea blends. Again, as with the taste results, the strongest dry green herbal aftertaste was detected in bush tea, special tea and in all bush tea blends. Rooibos and honey bush tea were the only two teas with a more woody-cinnamon aftertaste, which was in agreement with the findings of a previous study on honeybush tea [2]. Overall, for all seven teas, the earthy boiled potatoes aftertaste was very low $(1.18-1.92)$ as was also the case with the taste attributes. The astringent/dry mouth feel was very weak in the rooibos and honeybush teas, in contrast with bush tea, special tea and bush-special tea blends that had the most intense astringent/dry mouth feel of the seven teas. The strong astringent aftertaste could be a negative attribute and might contribute to consumer aversion towards bush tea and special tea [19]. Blending of bush tea with rooibos tea or honeybush tea could act as a de-bittering process to reduce the bitterness of bush tea.

\subsubsection{Colour}

The results regarding the colour scores of tea samples are depicted in Table 2 which revealed a significant variation $(p<0.0001)$ among different tea samples. In a similair manner, the orange colour was more described in honeybush and rooibos tea and the blend of bush tea and rooibos. Bush tea showed an intense green colour followed by special tea and the blend of bush tea and special tea. Blending bush tea with rooibos and honeybush tea reduced the green colour depicted in bush tea, positioning bush tea as a likeable tea. 
Table 2. Mean values and significant differences in aroma, taste, aftertaste, mouthfeel and colour of the seven selected teas.

\begin{tabular}{|c|c|c|c|c|c|c|c|c|c|c|}
\hline \multirow{2}{*}{$\begin{array}{l}\text { AROMA } \\
\text { AROMA }\end{array}$} & \multirow[t]{2}{*}{ CODE 1} & \multirow[t]{2}{*}{ CODE 2} & \multirow[t]{2}{*}{$p$-Value } & \multicolumn{7}{|c|}{ Intensity of Aroma, Taste, Aftertaste, Mouthfeel and Colour in Tea Samples } \\
\hline & & & & Bush & Honeybush & Special & Rooibos & $\begin{array}{l}\text { Bush and } \\
\text { honeybush }\end{array}$ & $\begin{array}{c}\text { Bush Tea and } \\
\text { Special Tea }\end{array}$ & $\begin{array}{l}\text { Bush and } \\
\text { Rooibos }\end{array}$ \\
\hline Sweet-caramel, maple syrup & Asweety & S1 & $<0.0001$ & $1.35^{\mathrm{bc}}$ & $3.15^{\mathrm{a}}$ & $1.25^{\mathrm{cd}}$ & $3.13^{\mathrm{a}}$ & $2.67^{\mathrm{a}}$ & $1.30 \mathrm{~cd}$ & $2.52^{\mathrm{a}}$ \\
\hline Honey—sweet typical honey & Ahoney & S2 & $<0.0001$ & $1.18^{\mathrm{cd}}$ & $2.81^{\mathrm{b}}$ & $1.00^{\mathrm{d}}$ & $3.98^{\mathrm{a}}$ & $2.40 \mathrm{bf}$ & $1.12^{\mathrm{dg}}$ & $2.80^{\text {be }}$ \\
\hline Green-cut grass & Agreen & S3 & $<0.0001$ & 4.22 be & $1.60^{\mathrm{a}}$ & $2.67^{\mathrm{ce}}$ & $1.43^{\mathrm{a}}$ & $3.20 \mathrm{~cd}$ & $3.9^{\mathrm{bd}}$ & 3.55 de \\
\hline Cooked spinach & Aspinach & S4 & $<0.0001$ & $1.85^{\mathrm{c}}$ & $1.00^{\mathrm{b}}$ & $5.20^{\mathrm{d}}$ & $1.00^{\mathrm{a}}$ & $1.12 \mathrm{ab}$ & $4.75^{\mathrm{ed}}$ & $1.05^{\mathrm{ab}}$ \\
\hline Dry green herbal—chai tea & Aherbal & S5 & $<0.0001$ & $3.95 \mathrm{bc}$ & $1.65^{\mathrm{a}}$ & $3.38^{\mathrm{cd}}$ & $1.30^{\mathrm{a}}$ & $2.95^{\mathrm{a}}$ & $3.45 \mathrm{bd}$ & $2.95^{\mathrm{a}}$ \\
\hline Earthy_-boiled potatoes, damp potting soil & Aearthy & S6 & $<0.0001$ & $2.02^{b c}$ & $1.25^{\mathrm{a}}$ & $2.17^{\mathrm{c}}$ & $1.07^{\mathrm{a}}$ & $1.25^{\mathrm{a}}$ & $2.12^{\mathrm{cd}}$ & $1.30^{\mathrm{a}}$ \\
\hline Perfume-floral, lavender & Aperfume & S7 & $<0.0001$ & $1.18 \mathrm{ac}$ & $4.62^{b}$ & $1.05^{\mathrm{ce}}$ & $2.00^{\mathrm{a}}$ & $3.02^{\mathrm{d}}$ & 1.20 ae & $1.77^{\mathrm{ac}}$ \\
\hline $\begin{array}{l}\text { Woody cinnamon, dry dusty, bark } \\
\text { TASTE }\end{array}$ & Awoody & S8 & 0.0075 & $1.48^{\mathrm{b}}$ & $2.25^{\mathrm{a}}$ & $1.32^{\mathrm{b}}$ & $1.73^{\mathrm{ab}}$ & $1.85^{\mathrm{ab}}$ & $1.50^{\mathrm{b}}$ & $1.48^{\mathrm{b}}$ \\
\hline Bitter-quinine, caffeine & Tbitter & S9 & $<0.0001$ & $4.47^{\mathrm{bd}}$ & $2.73^{\mathrm{a}}$ & $5.70^{\mathrm{ce}}$ & $3.25^{\mathrm{a}}$ & $3.58^{\mathrm{ad}}$ & $5.33^{e}$ & $4.00^{\mathrm{d}}$ \\
\hline Sweet—caramel, maple syrup & Tsweet & S10 & $<0.0001$ & $1.18^{\mathrm{b}}$ & $3.05^{\mathrm{a}}$ & $1.15^{\mathrm{cf}}$ & $2.77^{\text {ae }}$ & $2.38^{\text {de }}$ & $1.23^{\mathrm{f}}$ & $1.80^{\mathrm{bd}}$ \\
\hline Honey-sweet typical honey & Thoney & S11 & $<0.0001$ & $1.10^{\mathrm{bc}}$ & $2.58^{\mathrm{a}}$ & $1.05^{c}$ & $3.25^{\mathrm{a}}$ & $2.00^{\mathrm{ad}}$ & $1.05^{\text {ae }}$ & $2.12^{\mathrm{cd}}$ \\
\hline Rooibos & Trooibos & S12 & $<0.0001$ & $1.20^{\mathrm{cd}}$ & 3.45 be & $1.23^{\mathrm{dg}}$ & $4.95^{\mathrm{a}}$ & $3.45^{f}$ & $1.45^{\mathrm{cg}}$ & 3.75 ef \\
\hline Green-cut grass, mint & Tgreen & S13 & $<0.0001$ & $4.58^{\mathrm{cd}}$ & 1.57 be & $2.83 \mathrm{dg}$ & $1.52^{\mathrm{a}}$ & $3.55 \mathrm{bf}$ & $3.95^{\mathrm{cg}}$ & 3.98 ef \\
\hline Cooked spinach & Tspinach & S14 & $<0.0001$ & $1.77^{\mathrm{bd}}$ & $1.00^{\mathrm{a}}$ & $5.30^{\mathrm{ce}}$ & $1.00^{\mathrm{a}}$ & 1.10 be & $4.92 \mathrm{bf}$ & $1.30^{\mathrm{bd}}$ \\
\hline Dry green herbal—chai tea & Therbal & S15 & $<0.0001$ & $4.20^{\mathrm{b}}$ & $1.75^{\mathrm{a}}$ & $3.52^{\mathrm{cd}}$ & $1.32^{\mathrm{a}}$ & $3.52^{\mathrm{ab}}$ & $3.90^{\mathrm{d}}$ & $3.73^{\mathrm{ab}}$ \\
\hline Earthy_-boiled potatoes, damp potting soil & Tearthy & S16 & $<0.0001$ & $1.77 \mathrm{bc}$ & $1.32^{\mathrm{a}}$ & $2.23 \mathrm{~cd}$ & $1.12^{\mathrm{a}}$ & 1.45 ce & $2.05 \mathrm{cf}$ & $1.35^{\mathrm{cd}}$ \\
\hline Perfume-floral, lavender & Tperfume & S17 & $<0.0001$ & $1.18^{\mathrm{bcf}}$ & $4.55^{\mathrm{ab}}$ & $1.02^{\mathrm{ce}}$ & $1.92^{\mathrm{a}}$ & 2.80 af & 1.30 de & $1.62^{\mathrm{ba}}$ \\
\hline Woody cinnamon, dry dusty, bark & Twoody & S18 & 0.0002 & $1.43^{\mathrm{cd}}$ & $2.40^{\mathrm{b}}$ & $1.45^{\mathrm{cd}}$ & $1.82^{\mathrm{a}}$ & $1.85^{\mathrm{e}}$ & $1.32^{\mathrm{ad}}$ & $1.65^{\mathrm{ac}}$ \\
\hline Medicinal & Tmedicinal & S19 & $<0.0001$ & 2.52 cef & $1.25^{\mathrm{a}}$ & $3.42^{\mathrm{d}}$ & $1.10^{\mathrm{a}}$ & $1.82 \mathrm{ac}$ & $3.33 \mathrm{df}$ & $2.15^{\text {ce }}$ \\
\hline \multicolumn{11}{|l|}{ AFTERTASTE } \\
\hline Bitter & ATbitter & S20 & $<0.0001$ & $4.22 \mathrm{bd}$ & $2.60^{\mathrm{a}}$ & $5.67 \mathrm{cf}$ & 3.15 ae & 3.55 be & $5.28^{\mathrm{f}}$ & 3.80 de \\
\hline Green-cut grass, mint & ATgreen & S21 & $<0.0001$ & $3.85^{\mathrm{ceg}}$ & $1.52^{b}$ & $2.60 \mathrm{df}$ & $1.43^{\mathrm{a}}$ & $3.08^{\mathrm{cdf}}$ & $3.50^{\text {efg }}$ & 3.50 de \\
\hline Cooked spinach & ATspinach & $\mathrm{S} 22$ & $<0.0001$ & $1.55^{\mathrm{a}}$ & $1.00^{\mathrm{a}}$ & $4.60^{\mathrm{b}}$ & $1.00^{\mathrm{a}}$ & $1.07^{\mathrm{a}}$ & $4.22 \mathrm{bc}$ & $1.05^{\mathrm{a}}$ \\
\hline Dry green herbal—chai tea & ATherbal & S23 & $<0.0001$ & $3.92 \mathrm{bc}$ & $1.55^{\mathrm{a}}$ & $3.23 \mathrm{~cd}$ & $1.30^{\mathrm{a}}$ & 3.15 bce & 3.67 def & $3.23 \mathrm{bd}$ \\
\hline Woody cinnamon, dry dusty, bark & ATwoody & S24 & 0.0016 & $1.35 \mathrm{bdf}$ & $2.25^{\mathrm{a}}$ & $1.38^{b c}$ & $1.80^{\mathrm{abc}}$ & $1.52^{\text {cde }}$ & $1.43^{\mathrm{cf}}$ & $1.57^{\mathrm{cd}}$ \\
\hline $\begin{array}{c}\text { Earthy - boiled potatoes, damp potting soil } \\
\text { MOUTH FEEL }\end{array}$ & ATearthy & S25 & 0.0001 & $1.60^{\mathrm{ab}}$ & $1.18^{\mathrm{a}}$ & $1.82^{b}$ & $1.15^{\mathrm{a}}$ & $1.27^{\mathrm{a}}$ & $1.92^{b c}$ & $1.45^{\mathrm{abc}}$ \\
\hline $\begin{array}{l}\text { Astringent/dry } \\
\text { COLOUR }\end{array}$ & MFdry & S26 & $<0.0001$ & $4.42^{b d}$ & $3.05^{\mathrm{a}}$ & $5.40 \mathrm{cf}$ & $3.08^{\mathrm{a}}$ & 4.03 be & $5.05^{b f}$ & $3.77^{\mathrm{de}}$ \\
\hline Brown & Brown & & $<0.0001$ & $1.90^{\mathrm{b}}$ & $3.20^{\text {af }}$ & $6.05^{\mathrm{ce}}$ & $4.20 \mathrm{fg}$ & $2.45^{\mathrm{ab}}$ & 5.00 def & $4.65^{\mathrm{df}}$ \\
\hline Orange & Orange & & $<0.0001$ & $1.55^{\mathrm{bc}}$ & $4.70^{\mathrm{ae}}$ & $1.75^{\mathrm{cd}}$ & $5.35^{\mathrm{e}}$ & $3.65^{\mathrm{a}}$ & $1.80 \mathrm{bd}$ & $4.10^{\mathrm{a}}$ \\
\hline Green & Green & & $<0.0001$ & $5.70^{\mathrm{b}}$ & $1.15^{\mathrm{a}}$ & $4.10^{\mathrm{cd}}$ & $1.25^{\mathrm{a}}$ & 3.25 de & $4.35^{\text {ce }}$ & $1.85^{\mathrm{a}}$ \\
\hline
\end{tabular}

$\mathrm{a}, \mathrm{b}, \mathrm{c}, \mathrm{d}, \mathrm{e}, \mathrm{f}, \mathrm{g}$ different superscript letters signify statistically significant differences in the relative intensity of each tea. 
Figure 1 shows the results of the principal component analysis (PCA) of all tea samples and bush tea blend attributes on axis $1(76.08 \%)$ and axis $2(13.30 \%)$. The PCA (F1) biplot grouped honeybush and rooibos tea in the same cluster while the blend of bush tea with honeybush or rooibos was grouped together showing that both rooibos and honeybush share similar characteristics. Similarly, special tea and the blend of special tea with bush tea shared the same clustering as indicated by PCA 1 while bush tea was clustered alone. In contrast, PCA 2 (13.30\%) showed a distinct clustering of rooibos, honeybush, the rooibos and bush tea blend and the bush and honeybush tea blend, the other grouping being of bush, special tea and the bush and special tea blend.

PCA 1 shows that attributes such as ATwoody, Tsweet, Thoney, Ahoney, Twoody, Tperfume, were more profound in rooibos and honeybush tea. Blending with bush tea resulted in a mild flavour of Aperfume, Awoody, Asweet and Trooibos. Bush tea was mostly characterised by colour green, Aherbal, ATherbal, Therbal, ATgreen, Agreen and Tgreen while special tea had a brown colour, Tspinach, Aspinach, ATspinach, ATbitter, Tbitter, ATearthy, Aearthy and MFdry.

Biplot (axes F1 and F2: $89.39 \%$ )

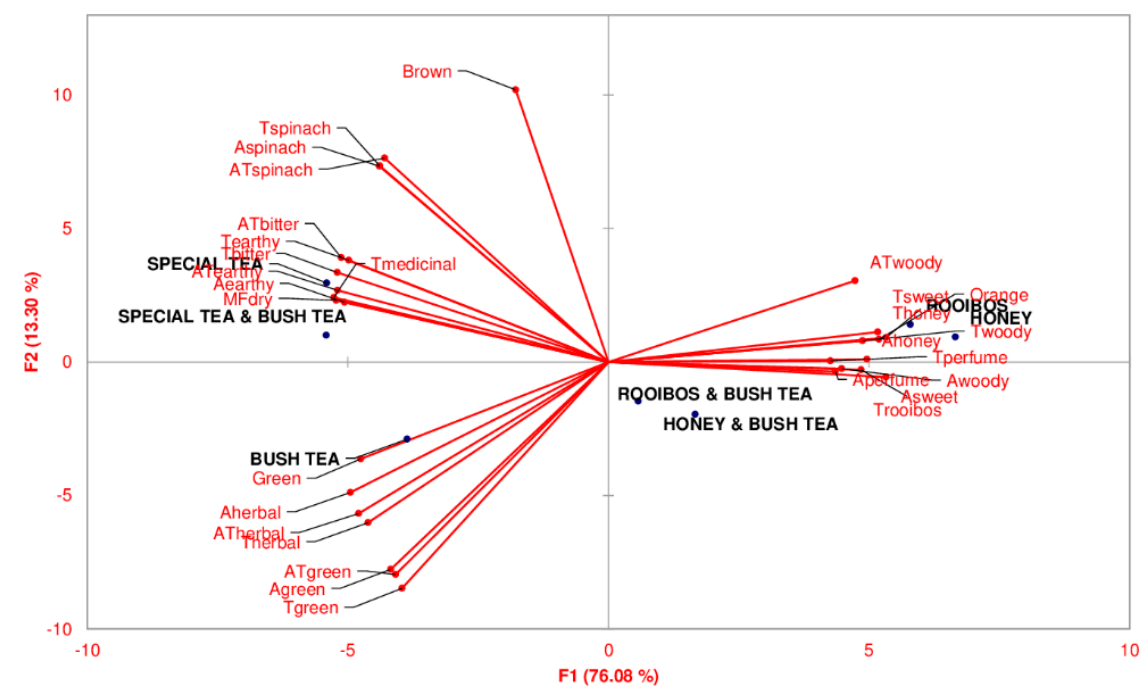

Figure 1. Principal component analysis (PCA) bi-plot showing distinct differences between the tea samples. The letters " $\mathrm{A}$ ", " $\mathrm{T}$ ", " $\mathrm{A}$ " and "MF" in front of an attribute name refer to aroma, taste, aftertaste and mouthfeel attributes, respectively.

\subsection{GC-MS Identification of Volatile Compounds in Selected Teas}

Seven tea samples were analysed and the representative total ion chromatogram (TIC) for each of these teas is presented in Figure 2 and Table 3. Raw data sourced from gas chromatography-mass spectrometer (GC-MS) is found under supplementary material (Table S2). A total of 58 volatile compounds in the tea extracts were detected by GC-MS. The identity of the compounds was determined by comparing their spectra to those of known compounds in the Mass Spectral Library (NIST08, NIST08s, FFNSC1.3). Compounds were selected for consideration on the basis of having a similarity cut-off of 800 and above. The identified volatile compounds and their relative area percentage, mean values and standard error are summarised in Table 3. Volatile compounds from different chemical groups such as terpenoids, alcohols, hydrocarbons, aldehydes, acids, furans, phenols, esters and ketones are known to influence the typical flavour of teas [21].

The volatile compounds (-)-carvone, (-)- $\alpha$-copaene, 2-furanmethanol, 2-methoxy-4-vinylphenol, acetic acid, $\alpha$-myrcene, $\alpha$-ocimene, apocynin, caryophyllene, d-limonene, geraniol, linalool, methyl salicylate, phenylethyl alcohol, phytol, piperonal, squalene, vanillin, hydroxyacetone, beta-ocimene, 2-methyl butyraldehyde, actinidiolide, dihydroactinidolide, terpinolene, (E,E)-2,4-heptadienal, 
maltol, cis-2,6-dimethyl-2,6-octadiene, p-allylphenol, trans-4-propenylsyringol, diacetone alcohol, cadina-1(10),4-diene, trans-verbenol, trans-geranylgeraniol, humulene, maltol, cis-ocimenol, and acetoin were tentatively identified in the tea samples.

(-)-Carvone (GC1), (-)- $\alpha$-copaene (GC3), caryophyllene (GC11), piperonal (GC29) trans-verbenol (GC52), trans-geranylgeraniol (GC53), and humulene (GC54) were among the compounds detected in special tea for which no study has previously been done regarding the GC-MS analysis of its volatile compound composition. 2-Furanmethanol (GC5) (a flavouring ingredient) was found in all teas except in the bush-special tea blend. This compound has previously been reported in oolong, green and black tea [22]. 2-Methoxy-4-vinylphenol (GC6) and dihydroactinidolide (GC35) were detected in all tea samples, albeit with slight differences in their relative abundance in the teas. 2-Methoxy-4-vinylphenol was identified as a key contributor to aroma compounds in tea beverages [23] while dihydroactinidolide was detected in Assam black tea and Darjeeling black tea [24]. Honeybush tea was shown to have $\alpha$-myrcene (GC8), which was subsequently detected also in the blend of bush and honeybush tea. This compound was previously identified in alcoholic beverages [25]. However, $\beta$-myrcene, the trans arrangement of myrcene, was previously identified in honeybush tea [26]. Geraniol (GC14), and cis-ocimenol (GC51), were detected only in honeybush tea.

Linalool (GC15) and D-limonene (GC12) were tentatively identified in bush and honeybush teas and the blend of both teas, congruent with the findings of Ntlhokwe et al. [27]. Bush tea was the only tea which had 2-methyl butyraldehyde (GC30), cis-2,6-dimethyl-2,6-octadiene (GC31), p-allylphenol (GC32), trans-isoeugenol (GC44), trans-4-propenylsyringol (GC45), diacetone alcohol (GC48), and Cadina-1(10),4-diene (GC42). Beta-Ocimene, (GC29) and Gamma-Terpinene (GC46) were previously detected in bush tea [28]. The distinct compounds found in rooibos tea were acetoin (GC57) and maltol (GC58).

Phenylethyl alcohol was detected in honeybush and rooibos teas and also in the blends of bush-honeybush and bush-rooibos teas. These results confirmed the findings of Marnewick (2009) [29] who identified phenylethyl alcohol in both teas. Phytol (GC18) was detected in all tea samples though there were slight variations in its relative abundance in the teas. Previous studies reported its presence in green, oolong and Pu-erh tea [21]. Squalene (GC21), pseudoionone (GC547) and glycerin (GC34) were the only compounds detected in bush tea and special tea. 
Table 3. Compounds detected and concentrations using a gas chromatography-mass spectrometer (GC-MS) in seven tea samples.

\begin{tabular}{|c|c|c|c|c|c|c|c|c|c|c|}
\hline Code & Name of Compounds & RT (m) & Odour Description & Bush Tea & Honeybush Tea & Special Tea & Rooibos Tea & $\begin{array}{c}\text { Bush: } \\
\text { Honeybush }\end{array}$ & Bush: Special & Bush: Rooibos \\
\hline GC1 & $\begin{array}{l}\text { (-)-Carvone } \\
\text { (E)-1-(2,3,6- }\end{array}$ & 18.39 & Spearmint-like herbal odour [30] & ND & ND & $0.025 \pm 0.007$ & ND & ND & ND & ND \\
\hline GC2 & $\begin{array}{l}\text { trimethylphenyl)buta- } \\
\text { 1,3-diene (TPB, 1) }\end{array}$ & 22.77 & - & $0.039 *$ & ND & $0.050 *$ & $0.100 *$ & $0.0022 *$ & $0.122 *$ & ND \\
\hline GC3 & $\alpha$-Copaene & 21.92 & Woody, spicy [31] & ND & ND & $0.11 \pm 0.04$ & ND & ND & ND & ND \\
\hline GC4 & 1-Pentanol & 4.25 & & ND & ND & 0.187 & ND & ND & 0.157 & ND \\
\hline GC5 & 2-Furanmethanol & 6.86 & Weak, creamy, burnt sugar [32] & $0.054 \pm 0.0 .022^{\mathrm{a}}$ & $0.266 \pm 0.083 \mathrm{ab}$ & $0.111 \pm 0.013 \mathrm{bc}$ & $0.0126^{\mathrm{bc} *}$ & $0.394 \pm 0.131^{\mathrm{a}}$ & ND & $0.116 \pm 0.029 \mathrm{bc}$ \\
\hline GC6 & 2-Methoxy-4-vinylphenol & 20.31 & Smoky [33] & $0.308 \pm 0.066^{c}$ & $0.422 \pm 0.149^{c}$ & $1.677 \pm 2.692 \mathrm{bc}$ & $6.834 \pm 0.989^{\mathrm{a}}$ & $0.460 \pm 0.052^{c}$ & $0.437 \pm 0.049^{c}$ & $3.419 \pm 0.124^{b}$ \\
\hline GC7 & Acetic acid & 2.51 & Acidic [34] & $0.421 \pm 0.263^{c}$ & $0.919 \pm 0.439 \mathrm{bc}$ & $0.405 \pm 0.260^{c}$ & $2.974 \pm 0.486^{\mathrm{a}}$ & $2.728 \pm 0.811^{\mathrm{a}}$ & $0.638 \pm 0.027^{c}$ & $1.493 \pm 0.287^{b}$ \\
\hline GC8 & $\alpha$-Myrcene & 10.85 & Sweet [35] & $0.121 \pm 0.022^{c}$ & $2.569 \pm 0.179^{\mathrm{a}}$ & ND & ND & $1.411 \pm 0.304^{\mathrm{b}}$ & $0.225 \pm 0.0 .072^{c}$ & $0.115^{c *}$ \\
\hline GC9 & $\alpha$-Ocimene & 12.66 & & $0.047^{c *}$ & $1.316 \pm 0.172^{\mathrm{a}}$ & ND & ND & $0.774 \pm 0.049^{b}$ & $0.168^{\mathrm{c} *}$ & ND \\
\hline GC10 & Apocynin & 24.79 & Sweet, somewhat vanilla-like [36] & $0.042 * c$ & $0.249 \pm 0.011^{b}$ & ND & $0.546 \pm 0.113^{\mathrm{a}}$ & $0.081 \mathrm{bc} *$ & ND & $0.262 \pm 0.044^{b}$ \\
\hline GC11 & Caryophyllene & 23.04 & - & ND & $\mathrm{ND}$ & $0.780 \pm 0.280^{\mathrm{a}}$ & $\mathrm{ND}$ & $\mathrm{ND}$ & $0.044^{\mathrm{a} *}$ & ND \\
\hline GC12 & D-Limonene & 11.94 & Citrus, lemon. [37] & $0.158 \pm 0.056^{\mathrm{d}}$ & $1.969 \pm 0.066^{\mathrm{a}}$ & $0.058 \pm 0.011 \mathrm{~d}$ & ND & $1.241 \pm 0.134^{\mathrm{b}}$ & $0.303 \pm 0.043^{c}$ & $0.099 \pm 0.016^{\mathrm{d}}$ \\
\hline GC13 & Furfural & 6.26 & - & $0.042 \pm 0.005^{\mathrm{cd}}$ & $0.882 \pm 0.068^{\mathrm{a}}$ & $0.040 \pm 0.009 \mathrm{~cd}$ & ND & $0.216 \pm 0.048^{\mathrm{b}}$ & $0.041 \pm 0.044 \mathrm{~cd}$ & $0.030 \pm 0.008^{\mathrm{d}}$ \\
\hline GC14 & Geraniol & 18.81 & Floral, woody [38] & ND & $0.183 \pm 0.020^{\mathrm{a}}$ & ND & ND & $0.113 \pm 0.009^{b}$ & ND & $\mathrm{ND}$ \\
\hline GC15 & Linalool & 14.28 & Fruity, floral [39] & $0.015 \pm 0.003^{c}$ & $0.161 \pm 0.015^{\mathrm{a}}$ & ND & ND & $0.106 \pm 0.020^{\mathrm{b}}$ & ND & ND \\
\hline GC16 & Methyl salicylate & 16.96 & Sweet, characteristic wintergreen [36] & ND & $0.038 \pm 0.008^{\mathrm{a}}$ & ND & $0.101 \pm 0.005$ & $0.153 \pm 0.113^{\mathrm{a}}$ & ND & ND \\
\hline GC17 & Phenylethyl alcohol & 14.66 & Floral [38] & ND & $0.502 \pm 0.081^{b}$ & ND & $0.919 \pm 0.288^{\mathrm{a}}$ & $0.206 \pm 0.020 \mathrm{bc}$ & ND & $0.118 \pm 0.081^{\mathrm{c}}$ \\
\hline GC18 & Phytol & 57.37 & Sweet, Floral [38] & $0.745 \pm 0.136^{b}$ & $1.286 \pm 0.136^{\mathrm{b}}$ & $6.848 \pm 2.991^{\mathrm{a}}$ & $1.377 \pm 0.203 \mathrm{~b}$ & $2.602 \pm 0.304^{b}$ & $5.174 \pm 0.651$ a & $1.407 \pm 0.070^{\mathrm{b}}$ \\
\hline GC19 & Piperonal & 20.78 & Cherry, vanilla, sweet anisic [36] & ND & ND & $0.058 \pm 0.041^{\mathrm{a}}$ & ND & ND & $0.274 \pm 0.267^{\mathrm{a}}$ & ND \\
\hline GC20 & Salicylic acid & 20.53 & 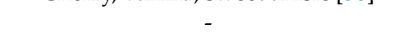 & $0.067^{b *}$ & $0.152^{b *}$ & $0.123 \pm 0.040^{\mathrm{b}}$ & $1.449 \pm 0.446^{\mathrm{a}}$ & $0.092 \pm 0.032 \mathrm{~b}$ & $\mathrm{ND}$ & $0.380^{b *}$ \\
\hline GC21 & Squalene & 108.63 & & $0.638 \pm .0229 \mathrm{ab}$ & ND & $1.279 \pm 0.719^{\mathrm{a}}$ & ND & $0.084 \pm 0.036^{b}$ & $0.611 \pm 0.066 \mathrm{ab}$ & $0.592 \pm 0.395 \mathrm{ab}$ \\
\hline GC22 & Vanillin & 22.58 & Vanilla-like, sweet [23] & $0.031^{\mathrm{b} *}$ & ND & ND & $0.710 \pm 0.184^{\mathrm{a}}$ & $0.091^{b *}$ & $0.091 \pm 0.042^{\mathrm{b}}$ & $0.389 \pm 0.043 \mathrm{ab}$ \\
\hline GC23 & Hydroxyacetone & 3.77 & - & $0.176 \pm 0.185^{a b}$ & $0.131^{b *}$ & ND & $0.487 \pm 0.128 \mathrm{ab}$ & $0.237 \pm 0.082 \mathrm{ab}$ & $0.677^{a *}$ & $0.219 \mathrm{ab} *$ \\
\hline GC24 & Propiophenone & 3.94 & - & $0.010 \pm 0.002^{b}$ & $0.068 \pm 0.038^{\mathrm{a}}$ & $0.045 \pm 0.001 \mathrm{ab}$ & $0.016^{\mathrm{b} *}$ & $0.022 \pm 0.016^{\mathrm{b}}$ & $0.025 \pm 0.020^{\mathrm{b}}$ & $0.031 \pm 0.026^{a b}$ \\
\hline GC25 & Butyrolactone & 8.45 & - & $0.263 \pm 0.160^{a}$ & $0.134 \pm 0.003^{\mathrm{a}}$ & ND & $0.098 \pm 0.010^{\mathrm{a}}$ & $0.260 \pm 0.093^{\mathrm{a}}$ & $\mathrm{ND}$ & $\mathrm{ND}$ \\
\hline GC26 & $\begin{array}{l}\text { 5-Methyl-2- } \\
\text { furancarboxaldehyde }\end{array}$ & 3.94 & - & $0.027 \pm 0.021^{\mathrm{b}}$ & $0.705 \pm 0.436^{\mathrm{a}}$ & $0.084 \pm 0.002^{\mathrm{b}}$ & $0.091 \pm 0.002^{\mathrm{b}}$ & $0.457 \pm 0.297 \mathrm{ab}$ & $0.085 \pm 0.041^{\mathrm{b}}$ & $0.033 \pm 0.004^{\mathrm{b}}$ \\
\hline GC27 & 2-Methylpyrazine & 6.02 & - & $0.030 \pm 0.012^{\mathrm{a}}$ & ND & $0.037 \pm 0.014^{\mathrm{a}}$ & ND & $0.023^{\mathrm{a} *}$ & $0.024 \pm 0.014 \mathrm{a}$ & $0.020 \pm 0.020^{\mathrm{a}}$ \\
\hline GC28 & $4^{\prime}$-Methylacetophenone & 16.65 & - & $0.043 \pm 0.007^{c}$ & $0.030 \pm 0.000^{c}$ & $0.239 \pm 0.085^{\mathrm{a}}$ & $0.072 \pm 0.019 \mathrm{bc}$ & $0.029 \pm 0.004^{c}$ & $0.131 \pm 0.009^{b}$ & $0.048 \pm 0.030^{c}$ \\
\hline GC29 & beta-Ocimene & 12.63 & [28] & $0.101^{\mathrm{a} *}$ & ND & ND & ND & $0.051 \pm 0.060^{\mathrm{a}}$ & $0.074 \pm 0.037^{a}$ & $0.040 \pm 0.026^{\mathrm{a}}$ \\
\hline GC30 & 2-methylbutyraldehyde & 3.91 & Fruity [39] & $0.205 \pm 0.015^{\mathrm{a}}$ & ND & ND & ND & $0.158 \pm 0.137^{a}$ & $0.424^{\mathrm{a} *}$ & ND \\
\hline GC31 & $\begin{array}{l}\text { cis-2,6-Dimethyl- } \\
\text { 2,6-octadiene }\end{array}$ & 11.18 & - & $0.129 \pm 0.022 \mathrm{ab}$ & ND & $\mathrm{ND}$ & $\mathrm{ND}$ & $0.061^{b *}$ & $0.217^{a *}$ & $\mathrm{ND}$ \\
\hline GC32 & p-Allylphenol & 21.11 & - & $0.039 \pm 0.021$ & ND & ND & ND & ND & ND & ND \\
\hline GC33 & $\begin{array}{l}\text { 1,1,6-Trimethyl-1,2- } \\
\text { dihydronaphthale }\end{array}$ & 21.28 & - & $0.075 \pm 0.032^{\mathrm{a}}$ & $0.082 \pm 0.108^{\mathrm{a}}$ & $0.089 \pm 0.025 a$ & $0.0602 \pm 0.030^{\mathrm{a}}$ & $0.091 \pm 0.052^{\mathrm{a}}$ & $0.112 \pm 0.019^{\mathrm{a}}$ & $0.129 \pm 0.111^{\mathrm{a}}$ \\
\hline GC34 & $\begin{array}{l}\text { Glycerin } \\
\text { att }\end{array}$ & 13.98 & - & $0.752 \pm 0.374^{\mathrm{b}}$ & ND & $0.339 \pm 0.340^{\mathrm{b}}$ & ND & $3.464^{\mathrm{a} *}$ & $0.464 \pm 0.582^{\mathrm{b}}$ & $0.120 \pm 0.047^{\mathrm{b}}$ \\
\hline GC35 & Dihydroactinidolide & 25.82 & Floral rose like [24] & $0.172 \pm 0.085^{\mathrm{d}}$ & $0.321 \pm 0.043^{\mathrm{d}}$ & $2.023 \pm 0.199 \mathrm{a}$ & $0.938 \pm 0.173^{b}$ & $0.382 \pm 0.037^{\mathrm{d}}$ & $1.174 \pm 0.233^{b}$ & $0.648 \pm 0.089^{c}$ \\
\hline GC36 & 1,1,6-trimethyltetralin & 21.38 & & $0.017 \pm 0.012^{b}$ & $0.080 \pm 0.066^{\mathrm{ab}}$ & $0.012 \pm 0.008^{b}$ & $0.119 \pm 0.054^{\mathrm{a}}$ & $0.029 \pm 0.010^{\mathrm{b}}$ & $0.055 \pm 0.057 \mathrm{ab}$ & $0.018 \pm 0.012^{b}$ \\
\hline GC37 & $\begin{array}{l}\text { 2-Hydroxy-2- } \\
\text { cyclopenten-1-one }\end{array}$ & 8.85 & - & $0.030 \pm 0.023^{\mathrm{d}}$ & $0.986 \pm 0.159^{a}$ & $0.188 \pm 0.055^{\mathrm{cd}}$ & $0.391 \pm 0.118^{b}$ & $0.287 \pm 0.189 \mathrm{bc}$ & $0.065 \pm 0.062^{\mathrm{d}}$ & $0.063 \pm 0.052^{\mathrm{d}}$ \\
\hline GC38 & $\alpha$-Angelica lactone & 7.17 & - & $0.039 \pm 0.016^{b c}$ & $0.986 \pm 0.159^{\mathrm{ab}}$ & $0.188 \pm 0.055^{\mathrm{a}}$ & $0.391 \pm 0.118^{b c}$ & $0.287 \pm 0.189^{\mathrm{a}}$ & $0.087 \pm 0.054 \mathrm{ab}$ & $0.063 \pm 0.052 \mathrm{ab}$ \\
\hline GC39 & Dehydro-beta-ionone & 24.64 & - & $0.003^{c *}$ & $0.043 \pm 0.001 \mathrm{bc}$ & $0.050 \mathrm{bc} *$ & $0.179 \pm 0.035^{\mathrm{a}}$ & $0.035 \pm 0.007^{c}$ & $0.087^{b *}$ & $0.054 \pm 0.033 \mathrm{bc}$ \\
\hline GC40 & Terpinolene & 13.80 & 37 & $0.376 \pm 0.406^{b c}$ & $0.906 \pm 0.047^{a}$ & ND & ND & $0.538 \pm 0.022^{\mathrm{b}}$ & $0.151 \pm 0.085^{\mathrm{cd}}$ & $0.036 \pm 0.005^{\mathrm{d}}$ \\
\hline
\end{tabular}


Table 3. Cont.

\begin{tabular}{|c|c|c|c|c|c|c|c|c|c|c|}
\hline Code & Name of Compounds & RT (m) & Odour Description & Bush Tea & Honeybush Tea & Special Tea & Rooibos Tea & $\begin{array}{c}\text { Bush: } \\
\text { Honeybush }\end{array}$ & Bush: Special & Bush: Rooibos \\
\hline GC41 & Cadina-1(10),4-diene & 25.68 & - & $0.010 \pm 0.007$ & ND & ND & ND & ND & ND & ND \\
\hline GC42 & 3-Thujene & 11.15 & - & 0.050 a* & $0.147 \pm 0.119^{a}$ & ND & ND & $0.080 \pm 0.003^{\mathrm{a}}$ & ND & ND \\
\hline GC43 & Methyl glycolate & 2.70 & - & $0.205 *$ & ND & $\mathrm{ND}$ & ND & ND & ND & 0.125 * \\
\hline GC44 & trans-Isoeugenol & 23.78 & - & $0.090 \pm 0.071$ & ND & ND & ND & ND & ND & ND \\
\hline GC45 & $\begin{array}{c}\text { trans-4- } \\
\text { PROPENYLSYRINGOL }\end{array}$ & 31.90 & - & $0.020 \pm 0.023$ & ND & ND & ND & $0.222 *$ & ND & ND \\
\hline GC46 & Gamma-Terpinene & 12.89 & & $0.033 \pm 0.002$ & $0.209 \pm 0.077$ & ND & ND & ND & ND & ND \\
\hline GC47 & Pseudoionone & 39.33 & - & $0.791 \pm 0.098^{\mathrm{bc}}$ & $\mathrm{ND}$ & $1.317 \mathrm{ab} *$ & ND & $0.643^{\mathrm{c} *}$ & $1.615 \pm 0.179 \mathrm{a}$ & $0.941 \mathrm{bc} *$ \\
\hline GC48 & Diacetone alcohol & 7.72 & - & $0.016 *$ & ND & ND & ND & ND & ND & ND \\
\hline GC49 & (E,E)-2,4-heptadienal & 11.47 & fatty, nutty, hay $[24,40,41]$ & $0.010^{b *}$ & $0.027 \pm 0.023^{b}$ & ND & $0.162 \pm 0.038^{b}$ & $0.723 \pm 0.301^{\mathrm{a}}$ & $0.239 \mathrm{~b} *$ & $0.219 \pm 0.0217^{b}$ \\
\hline GC50 & cis-Ocimenol & 16.17 & - & ND & $0.346 \pm 0.374$ & ND & ND & ND & ND & ND \\
\hline GC51 & trans-Verbenol & 15.53 & - & ND & ND & $0.325 \pm 0.118$ & ND & ND & ND & $\mathrm{ND}$ \\
\hline GC52 & $\begin{array}{l}\text { 6,10,14- } \\
\text { Trimethylpentadecan-2-one }\end{array}$ & 39.33 & - & $0.651^{b *}$ & $0.310^{c *}$ & ND & $0.719 \pm 0.066 \mathrm{ab}$ & $0.606 \pm 0.094^{b}$ & $0.567 \pm 0.005^{b}$ & $0.865 \pm 0.082^{a}$ \\
\hline GC53 & trans-Geranylgeraniol & 48.81 & - & ND & ND & $0.292 \pm 0.033$ & ND & ND & ND & ND \\
\hline GC54 & Humulene & 23.88 & - & ND & ND & $0.296 \pm 0.342$ & ND & ND & ND & ND \\
\hline GC55 & Butyrovanillone & 27.66 & - & 0.007 a* & $0.414 \pm 0.470 \mathrm{a}$ & $0.009 \pm 0.005 \mathrm{a}$ & $0.690 \pm 0.629 \mathrm{a}$ & $0.071 \pm 0.029 \mathrm{a}$ & $0.021 \pm 0.017^{\mathrm{a}}$ & $0.480 \pm 0.303^{a}$ \\
\hline GC56 & Homovanillyl alcohol & 26.03 & - & $\mathrm{ND}$ & ND & ND & $0.243^{a *}$ & $0.689 \pm 0.466^{\mathrm{a}}$ & ND & ND \\
\hline GC57 & Acetoin & 3.88 & - & ND & ND & ND & $0.252 \pm 0.094$ & ND & ND & ND \\
\hline GC58 & Maltol & 14.65 & Caramel [42] & ND & ND & ND & $0.319 \pm 0.012^{\mathrm{a}}$ & $0.029 \pm 0.007^{b}$ & ND & ND \\
\hline
\end{tabular}

Comparison of measured peak areas for annotated compounds in selected herbal teas with tentative identification. Level of significance was determined. a,b,c, Different superscript letters signify statistically significant differences in the relative amounts of the compounds in each tea. ND. Not detected. RT. Retention time. ${ }^{a, b, c, d}$ are taken to signify statistically significant differences in the relative intensity of each tea. ${ }^{*}$ Indicate that the experiment detected one value out of the three repitations. 

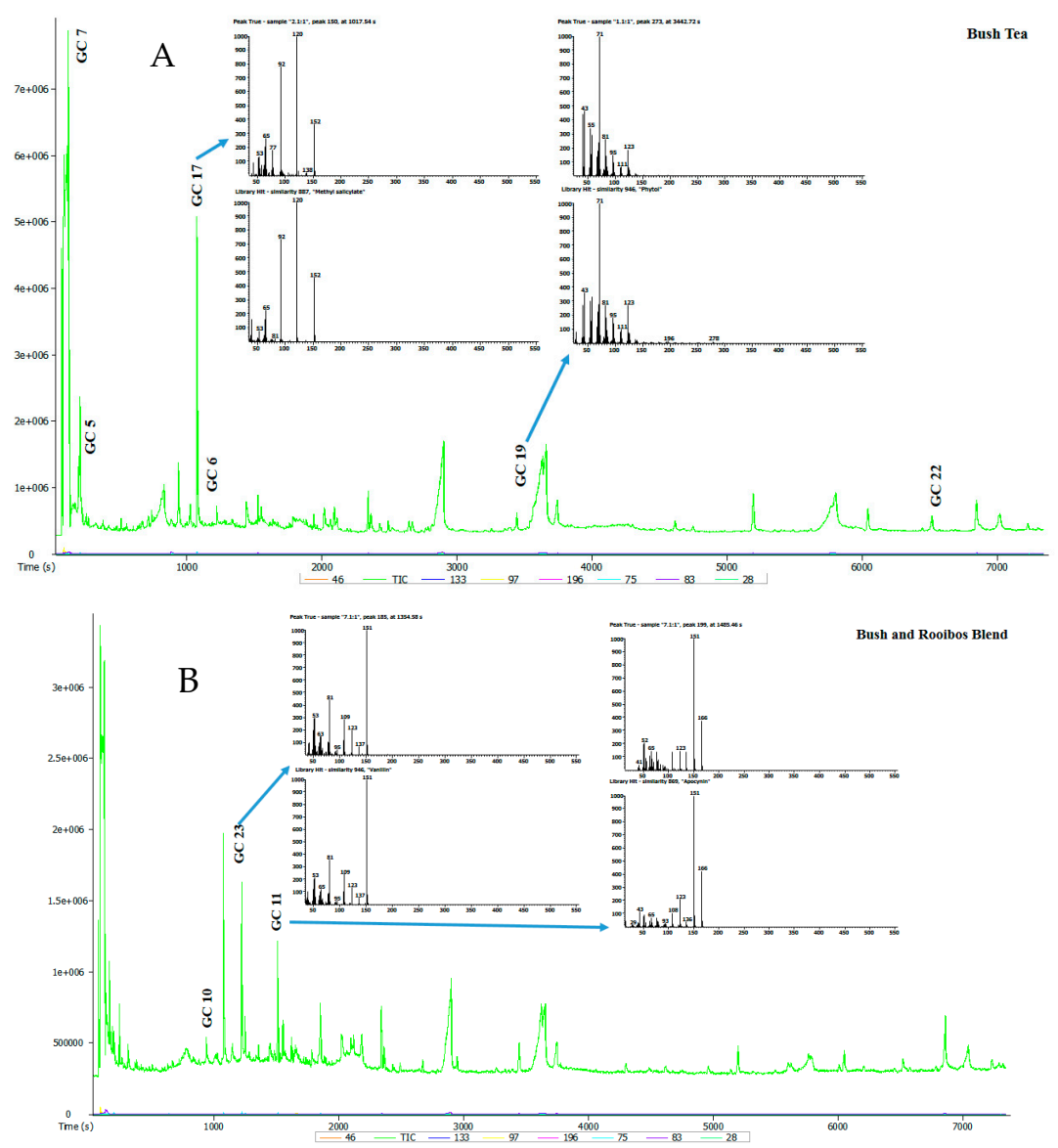

Figure 2. (A,B) Typical total ion chromatogram of the volatile compounds in selected tea samples.

\subsection{Relationships between Descriptive Sensory and Volatile Compound Analyses in Selected Teas}

The Partial Least Squares Regression (PLSR) biplot of the selected herbal teas, descriptive sensory attributes and volatile compounds is shown in Figure 3. Special tea lies slightly outside the confidence ellipse, indicating that it might be influential in the PLSR analysis. This trend is followed by honeybush tea. When variables on the map were proximal, they represent a closer relationship among the sensory attributes and volatile compounds. The variable importance plot showed 25 predictors with Variable Importance in Projection (VIP) values exceeding 0.8 , indicating that 25 of the 26 sensory attributes were influential in determining the two factors. Dependent variables, as explained by the model, are reflected in the fact that, except the points for (-)-carvone (GC1), (E)-1-(2,3,6-trimethylphenyl)buta-1,3-diene (GC2), butyrolactone (GC25), 2-methyl butyraldehyde (GC30), and diacetone alcohol (GC48), which are within the $25 \%$ circle, the others are near either the $50 \%, 75 \%$ or the $100 \%$ circle.

Volatile compounds are key contributors to tea flavour [33]. The typical flavour of each tea type is influenced by plant morphology and the degree of fermentation [41,43]. 2-furanmethanol (weak, creamy, burnt sugar), d-limonene (citrus, lemon), $\alpha$-myrcene (sweet), geraniol (floral, woody), linalool (fruity, floral), phenylethyl alcohol (floral) and apocynin (sweet) were found in honeybush tea and were correlated with the taste profile perfume and woody, woody aftertaste and sweet aroma. Honeybush tea showed a high score on sweet taste and had a high relative abundance of $\alpha$-myrcene, linalool and apocynin. Phenylethyl alcohol was reported in honeybush tea and was shown to impart a sweet taste [29]. The sensory evaluation did not include burnt sugar or lemon in the assessment; therefore, any volatile compounds associated with such attributes were not compared.

(E,E)-2,4-heptadienal (nutty, hay) and maltol (caramel) were located in the quadrant between rooibos and honeybush. Though acetic acid was a predominant compound in all tea samples, its relative abundance was higher in rooibos, honeybush tea and the bush-honeybush tea blend. Rooibos tea was 
associated with phenolic compounds, 2-methoxy-4-vinylphenol (smoky) and vanillin (vanilla-like, sweet). The flavour component and the volatile compounds of any tea are greatly influenced by post-harvest activities such as fermentation, which contribute to the sweet taste in tea [41,43]. The sweet caramel taste in fermented rooibos tea and honeybush tea could be as a result of fermentation.

Squalene had a negative correlation with all tea samples except for special tea. Special tea was coupled together with a spinach (S4) and earthy aroma (S6), a bitter (S9), earthy (S16) taste and a spinach (S22), earthy (S25) aftertaste together with an astringent mouthfeel (S26). It is the only tea that scored high on bitterness and astringency, attributes, which could contribute to consumers being averse to it. However, blending it with bush tea could act as a modulating factor. From the present study, the major aroma-active volatile compound found in the quadrant between bush tea and the blend of bush tea and special tea and which possess a medicinal, herbal, bitter and astringent taste included (-)-carvone (spearmint-like herbal). Special tea is associated with phytol (sweet, floral), $\alpha$-copaene (woody), piperonal (cherry, vanilla, sweet anisic), dihydroactinidolide (floral, rose-like) which does not exhibit the descriptive sensory attribute of bitter taste described in special tea. However, special attention should be given to the characterisation of volatile compounds in this tea since no data are currently available. Furthermore, tea fermentation, as well as blending special tea at different ratios with honeybush and rooibos tea, which exhibited a sweet taste, will help with reducing the bitterness.

The volatile compounds closely linked to bush tea and special tea were 2-methyl butyraldehyde (fruity) and (-)-carvone (spearmint-like, herbal), respectively. The sensory attributes associated with bush tea were green and herbal aroma, green and herbal taste, green and herbal aftertaste. While (-)-carvone shares the herbal sensory attributes, 2-methyl butyraldehyde is known to exhibit a fruity attribute [39]. The poor correlation might have been attributed to the fact that many volatile compounds are responsible for a particular flavour sensation [44]. Furthermore, GC-MS data output revealed multiple compounds which might not have been further discussed due to the lack of previous literature or low cut-off similarity values. Bush tea and all its blends contributed $25 \%$ or less to the variation, indicating a modifying factor when different teas are combined.

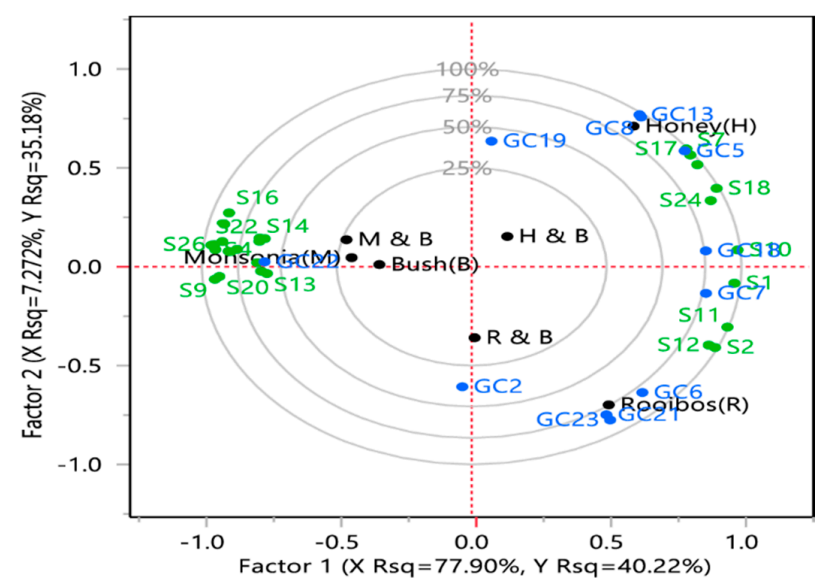

Figure 3. Partial least square regression analysis of descriptive sensory and gas chromatography data. Selected teas: bush tea (B), honeybush tea (H), (C) special tea (M), rooibos (R), 50\% honeybush tea plus $50 \%$ bush tea ( $\mathrm{H}$ and $\mathrm{B}$ ), 50\% special tea plus $50 \%$ bush tea and $50 \%$ rooibos tea plus $50 \%$ bush tea ( $R$ and $B)$. Tentative identification of compounds: GC2, (E)-1-(2,3,6-trimethylphenyl)buta-1,3-diene (TPB, 1); GC5, 2-Furanmethanol; GC6, 2-Methoxy-4-vinylphenol; GC7, Acetic acid; GC8, $\alpha$-myrcene; GC13, D-Limonene; GC16, Linalool; GC17, Methyl salicylate; GC18, Phenylethyl Alcohol; GC19, Phytol; GC30, Ocimene; GC32, 2-Methyl butyraldehyde; GC37, Dihydroactinidolide; GC41, Terpinolene; GC53, (E,E)-2,4-heptadienal; GC59, Maltol. Sensory data: S1, Asweet; S2, Ahoney, S3, Agreen; S4, Aspinach, S5, Aherbal; S6, A, Aearthy; S7, Afloral; S8, Awoody; S9, Tbitter; S10, TSweet; S11, Honey; S12, Trooibos; S13, Tgreen; S14, Tspinach; S15. Therbal; S16, Tearthy; S17, Tperfume; S18, Twoody; S19, Tmedicinal; S20, ATbitter; S21, ATgreen; S22, ATspinach; S23, ATherbal; S24, ATwoody; S25, ATearthy; S26, MFdry. 


\section{Conclusions}

From the results, it is clear that the two indigenous bush teas (bush tea and special tea) and the blend of these two teas were characterised by a bitter flavour characteristic. Bush teas also had a strong green-cut grass, minty, dry green herbal-chai tea and medicinal aroma and flavour characteristic. Rooibos and honeybush teas were characterised by a stronger rooibos, sweet caramel, maple syrup and sweet typical honey aroma and flavours. Honeybush tea and the honeybush-bush tea blend were characterised by the strongest perfume aroma. The toning down of aversive flavour components in bush tea by the combination of honey and rooibos was a positive attribute and could serve as a motivation for the commercialisation of bush tea.

Although volatile compounds, namely 2-furanmethanol, d-limonene, phenylethyl alcohol, linalool, geraniol, apocynin and $\alpha$-myrcene, were found in honeybush tea, together with sweet aroma and woody cinnamon, it is still difficult to conclusively assume that the compounds mentioned are responsible for the descriptive sensory attributes. Some compounds which are responsible for a sweet, floral sensory flavour, such as $\alpha$-copaene, piperonal, phytol, dihydroactinidolide, and 2-methyl butyraldehyde were also found in special tea and/or bush tea, which have bitterness and medicinal characteristics. More targeted compound identification could provide conclusive data on which compound is responsible for the bitter taste of bush and special tea.

Supplementary Materials: The following are available online at http://www.mdpi.com/2304-8158/9/4/496/s1, Table S1: Raw data from descriptive sensory evaluation, Table S2: Raw data from the data sourced from gas chromatography-mass spectrometer (GC-MS).

Author Contributions: Conceptualization, F.N.M., and F.M.; methodology F.N.M., and F.M.; formal analysis, L.K.D., and F.M.; investigation, F.N.M., and F.M.; writing-original draft preparation, all; Supervision, F.N.M., and L.J.M.; Funding Acquisition, F.M. All authors have read and agreed to the published version of the manuscript.

Funding: This work was supported by the Research Department, University of South Africa (grant number 358600).

Conflicts of Interest: The authors declare no conflict of interest.

\section{References}

1. Malongane, F.; McGaw, L.J.; Mudau, F.N. The synergistic potential of various teas, herbs and therapeutic drugs in health improvement: A review. J. Sci. Food Agric. 2017, 97, 4679-4689. [CrossRef] [PubMed]

2. Jolley, B.; van der Rijst, M.; Joubert, E.; Muller, M. Sensory profile of rooibos originating from the Western and Northern Cape governed by production year and development of rooibos aroma wheel. S. Afr. J. Bot. 2017, 110, 161-166. [CrossRef]

3. Theron, K.A.; Muller, M.; van der Rijst, M.; Cronje, J.C.; le Roux, M.; Joubert, E. Sensory profiling of honeybush tea (Cyclopia species) and the development of a honeybush sensory wheel. Food Res. Int. 2014, 66, 12-22. [CrossRef]

4. Nchabeleng, L.; Mariga, I.; Ngezimana, W.; Mudau, F. Bush tea (Athrixia phylicoides dc.) Success stories in South Africa A review. Crop Prod. 2013, 1, 37-43.

5. Mamphiswana, N.D.; Mashela, P.W.; Mdee, L.K. Distribution of total phenolics and antioxidant activity in fruit, leaf, stem and root of Monsonia burkeana. Afr. J. Agric. Res. 2010, 5, 2570-2575.

6. Tshivhandekano, I.; Ntushelo, K.; Ngezimana, W.; Tshikalange, T.E.; Mudau, F.N.; Tshikalange, E.; Mudau, F.N. Chemical compositions and antimicrobial activities of Athrixia phylicoides DC. (bush tea), Monsonia burkeana (special tea) and synergistic effects of both combined herbal teas. Asian Pac. J. Trop. Med. 2014, 4, 697-702. [CrossRef]

7. Koch, I.S.; Muller, M.; Joubert, E.; Van der Rijst, M.; Næs, T. Sensory characterization of rooibos tea and the development of a rooibos sensory wheel and lexicon. Food Res. Ingternational 2012, 46, 217-228. [CrossRef]

8. Joubert, E.; de Beer, D.; Malherbe, C.J. Herbal teas-Exploring untapped potential and strengthening commercialisation. S. Afr. J. Bot. 2017, 110, 1-3. [CrossRef]

9. Malongane, F.; McGaw, L.J.; Nyoni, H.; Mudau, F.N. Metabolic profiling of four South African herbal teas using high resolution liquid chromatography-mass spectrometry and nuclear magnetic resonance. Food Chem. 2018, 257, 90-100. [CrossRef] 
10. Singh-Ackbarali, D.; Maharaj, R. Sensory Evaluation as a Tool in Determining Acceptability of Innovative Products Developed by Undergraduate Students in Food Science and Technology at The University of Trinidad and Tobago. J. Curric. Teach. 2014, 3, 10-27. [CrossRef]

11. Welna, M.; Szymczycha-madeja, A.; Stelmach, E.; Pohl, P. Critical Reviews in Analytical Chemistry Speciation and Fractionation of Elements in Tea Infusions Speciation and Fractionation of Elements in Tea Infusions. Crit. Rev. Anal. Chem. 2017, 42, 349-365. [CrossRef]

12. Lee, J.; Chambers, D.H.; Chambers, E., IV. A comparison of the flavor of green teas from around the world. J. Sci. Food Agric. 2014, 94, 1315-1324. [CrossRef] [PubMed]

13. Lucak, C.L.; Delwiche, J.F. Efficacy of Various Palate Cleansers with Representative Foods. Chemosens. Percept. 2009, 2, 32-39. [CrossRef]

14. Owuor, P.O. Analysis and Tasting. In TEA; Elsevier Science: Kenya, Africa, 2003; pp. 5757-5762.

15. Simiqueli, A.A.; Minim, V.P.R.; dos Santos Navarro, R.D.C.; da Silva, A.N.; Minim, L.A. How many assessors are necessary for the Optimized Descriptive Profile when associated with training? Food Qual. Prefer. 2015, 44, 62-69. [CrossRef]

16. Lee, S.M.; Chung, S.-J.; Lee, O.-H.; Lee, H.-S.; Kim, Y.-K.; Kim, K.-O. Procedure of sample preparation, presentation, procedure and sensory descriptive analysis of green tea. J. Sens. Stud. 2007, 23, 450-467. [CrossRef]

17. Eloff, J.N. Which extractant should be used for the screening and isolation of antimicrobial components from plants? J. Ethnopharmacol. 1998, 60, 1-8. [CrossRef]

18. Wu, Y.; Lv, S.; Lian, M.; Wang, C.; Gao, X.; Meng, Q. Study of characteristic aroma components of baked Wujiatai green tea by HS-SPME/GC-MS combined with principal component analysis. CyTA J. Food 2016, 6337, 1-10. [CrossRef]

19. Drewnowski, A.; Gomez-Carneros, C. Bitter taste, phyonutrients, and the consumer: A review. Am. J. Clin. Nutr. 2000, 72, 1424-1435. [CrossRef]

20. Joubert, E.; Schultz, H. Production and quality aspects of rooibos tea and related products. A review. J. Appl. Bot. Food Qual. 2012, 80, 138-144.

21. Zheng, X.Q.; Li, Q.S.; Xiang, L.P.; Liang, Y.R. Recent advances in volatiles of teas. Molecules 2016, $21,338$. [CrossRef]

22. Baldermann, S.; Yang, Z.; Katsuno, T.; Tu, V.A.; Mase, N.; Nakamura, Y.; Watanabe, N. Discrimination of green, oolong, and black teas by GC-MS analysis of characteristic volatile flavor compounds. Am. J. Anal. Chem. 2014, 5, 620-632. [CrossRef]

23. Schuh, C.; Schieberle, P. Characterization of the key aroma compounds in the beverage prepared from Darjeeling black tea: Quantitative differences between tea leaves and infusion. J. Agric. Food Chem. 2006, 54, 916-924. [CrossRef] [PubMed]

24. Kang, S.; Yan, H.; Zhu, Y.; Liu, X.; Lv, H.P.; Zhang, Y.; Dai, W.D.; Guo, L.; Tan, J.F.; Peng, Q.H.; et al. Identification and quantification of key odorants in the world's four most famous black teas. Food Res. Int. 2019, 121, 73-83. [CrossRef] [PubMed]

25. Śliwińska, M.; Wiśniewska, P.; Dymerski, T.; Wardencki, W.; Namieśnik, J. Authenticity Assessment of the “Onisiówka” Nalewka Liqueurs Using Two-Dimensional Gas Chromatography and Sensory Evaluation. Food Anal. Methods 2017, 10, 1709-1720. [CrossRef]

26. Le Roux, M.; Cronje, J.C.; Joubert, E.; Burger, B.V. Chemical characterization of the constituents of the aroma of honeybush, Cyclopia genistoides. S. Afr. J. Bot. 2008, 74, 139-143. [CrossRef]

27. Ntlhokwe, G.; Tredoux, A.G.J.; Górecki, T.; Edwards, M.; Vestner, J.; Muller, M.; Erasmus, L.; Joubert, E.; Christel Cronje, J.; de Villiers, A. Analysis of honeybush tea (Cyclopia spp.) volatiles by comprehensive two-dimensional gas chromatography using a single-stage thermal modulator. Anal. Bioanal. Chem. 2017, 409, 4127-4138. [CrossRef]

28. Tshivhandekano, I.; Ngezimana, W.; Tshikalange, T.E.; Makunga, N.P.; Mudau, F.N. Nitrogen application influences quality, pharmacological activities and metabolite profiles of Athrixia phylicoides DC. (Bush tea) cultivated under greenhouse and field conditions. Acta Agric. Scand. Sect. B Soil Plant Sci. 2018, 68, 388-400.

29. Marnewick, J.L. Rooibos and Honeybush: Recent Advances in Chemistry, Biological Activity and Pharmacognosy. Afr. Nat. Plant Prod. New Discov. Challenges Chem. Qual. 2009, 1021, 277-294. 
30. Leitereg, T.J.; Guadagni, D.G.; Harris, J.; Mon, T.R.; Teranishi, R. Chemical and Sensory Data Supporting the Difference between the Odors of the Enantiomeric Carvones. J. Agric. Food Chem. 1971, 19, 785-787. [CrossRef]

31. Iwasa, M.; Nakaya, S.; Maki, Y.; Marumoto, S.; Usami, A.; Miyazawa, M. Identification of aroma-active compounds in essential oil from Uncaria Hook by gas chromatography- mass spectrometry and gas chromatography-olfactometry. J. Oleo Sci. 2015, 64, 825-833. [CrossRef]

32. Lee, S.J.; Moon, T.W.; Lee, J. Increases of 2-Furanmethanol and Maltol in Korean Red Ginseng during Explosive Puffing Process. J. Food Sci. 2010, 75, 147-151. [CrossRef] [PubMed]

33. Gong, X.; Han, Y.; Zhu, J.; Hong, L.; Zhu, D.; Liu, J.; Zhang, X.; Niu, Y.; Xiao, Z. Identification of the aroma-active compounds in Longjing tea characterized by odor activity value, gas chromatographyolfactometry, and aroma recombination. Int. J. Food Prop. 2017, 20, 1107-1121. [CrossRef]

34. Kraujalyte, V.; Pelvan, E.; Alasalvar, C. Volatile compounds and sensory characteristics of various instant teas produced from black tea. Food Chem. 2016, 194, 864-872. [CrossRef] [PubMed]

35. Lin, J.; Dai, Y.; Guo, Y.; Xu, H.; Wang, X. Volatile profile analysis and quality prediction of Longjing tea (Camellia sinensis) by HS-SPME/GC-MS. J. Zhejiang Univ. Sci. B 2012, 13, 972-980. [CrossRef] [PubMed]

36. Zhang, S.; Mueller, C. Comparative analysis of volatiles in traditionally cured bourbon and ugandan vanilla bean (vanilla planifolia) extracts. J. Agric. Food Chem. 2012, 60, 10433-10444. [CrossRef]

37. Sun, H.; Ni, H.; Yang, Y.; Chen, F.; Cai, H.; Xiao, A. Sensory evaluation and gas chromatography-mass spectrometry (GC-MS) analysis of the volatile extracts of pummelo (Citrus maxima ) peel. Flavour Fragr. J. 2014, 29, 305-312. [CrossRef]

38. Jumtee, K.; Komura, H.; Bamba, T.; Fukusaki, E. Predication of Japanese green tea (Sen-cha) ranking by volatile profiling using gas chromatography mass spectrometry and multivariate analysis. J. Biosci. Bioeng. 2011, 112, 252-255. [CrossRef]

39. Chen, X.; Chen, D.; Jiang, H.; Sun, H.; Zhang, C.; Zhao, H.; Li, X.; Yan, F.; Chen, C.; Xu, Z. Aroma characterization of Hanzhong black tea (Camellia sinensis) using solid phase extraction coupled with gas chromatography-mass spectrometry and olfactometry and sensory analysis. Food Chem. 2019, 274, 130-136. [CrossRef]

40. Lv, H.P.; Zhong, Q.S.; Lin, Z.; Wang, L.; Tan, J.F.; Guo, L. Aroma characterisation of Pu-erh tea using headspace-solid phase microextraction combined with GC/MS and GC-olfactometry. Food Chem. 2012, 130, 1074-1081. [CrossRef]

41. Feng, Z.; Li, Y.; Li, M.; Wang, Y.; Zhang, L.; Wan, X.; Yang, X. Tea aroma formation from six model manufacturing processes. Food Chem. 2019, 285, 347-354. [CrossRef]

42. Du Preez, B.V.P.; de Beer, D.; Moelich, E.I.; Muller, M.; Joubert, E. Development of chemical-based reference standards for rooibos and honeybush aroma lexicons. Food Res. Int. 2019, 127, 108734. [CrossRef] [PubMed]

43. Yang, Z.; Baldermann, S.; Watanabe, N. Recent studies of the volatile compounds in tea. FRIN 2013, 53, 585-599. [CrossRef]

44. Chambers, E., IV; Koppel, K. Associations of volatile compounds with sensory aroma and flavor: The complex nature of flavor. Molecules 2013, 18, 4887-4905. [CrossRef] [PubMed]

(C) 2020 by the authors. Licensee MDPI, Basel, Switzerland. This article is an open access article distributed under the terms and conditions of the Creative Commons Attribution (CC BY) license (http://creativecommons.org/licenses/by/4.0/). 